\title{
ASSESSMENT OF SOLAR PV POWER POTENTIAL IN THE ASIA PACIFIC REGION WITH REMOTE SENSING CONSIDERING THE EFFECTS OF HIGH TEMPERATURE, DUST AND SNOW
}

\author{
J. A. Principe ${ }^{1,2, *}$, W. Takeuchi ${ }^{2}$ \\ ${ }^{1}$ Department of Geodetic Engineering, University of the Philippines Diliman, Quezon City - japrincipe@up.edu.ph \\ ${ }^{2}$ Institute of Industrial Science, The University of Tokyo, Japan - wataru@iis.u-tokyo.ac.jp
}

Commission IV

KEY WORDS: Solar PV power, AHI8, MODIS, GSMaP, AMSR-E, dust, temperature, snow

\begin{abstract}
:
The last half century has witnessed the increasing trend of renewable energy utilization with solar photovoltaic (PV) systems as one of the most popular option. Solar PV continues to supplement the main grid in powering both commercial establishments (mainly for reduced electricity expense) as well as residential houses in isolated areas (for basic energy requirement such as for lighting purposes). The objective of this study is to assess the available solar PV power $\left(P_{P V}\right)$ potential considering the effects of high temperature, dust and snow in the Asia Pacific region. The $P_{P V}$ potential was estimated considering the effects of the said meteorological parameters using several satellite data including shortwave radiation from Advanced Himawari Imager 8 (AHI8), MOD04 aerosol data from Moderate Resolution Imaging Spectroradiometer (MODIS), precipitation rate from Global Satellite Mapping of Precipitation (GSMaP), air temperature from NCEP/DOE AMIP-II Reanalysis-2 data, and snow water equivalent (SWE) from Microwave Scanning Radiometer for the Earth Observing System (AMSR-E). The model is validated by comparing its outputs with the measured PV power from two solar PV installations in Bangkok, Thailand and Perth, Australia. Results show that maximum $P_{P V}$ is estimated at $2.5 \mathrm{GW}$ (cell efficiency of $17.47 \%$ ) for the region with the maximum decrease in $P_{P V}$ estimated to be about $<2 \%, 22 \%$ and $100 \%$ due to high temperature (temperature coefficient of power $=0.47 \% / \mathrm{K}$ ), dust and snow, respectively. Moreover, areas in India and Northern China were observed to experience the effects of both dust and temperature during MarchApril-May (MAM) season. Meanwhile, countries located in the higher latitudes were severely affected by snow while Australia by high temperature during Dec-Jan-Feb (DJF) season. The model has a mean percentage prediction error (PPE) range of 5\% to18\% and $7 \%$ to $23 \%$ in seasonal and monthly estimations, respectively. Outputs from this study can be used by stakeholders of solar PV in planning for small-scale or large-scale solar PV projects in the solar rich region of Asia Pacific.
\end{abstract}

\section{INTRODUCTION}

The rising global demand for energy was inevitable due to the need to support the energy requirements of an increasing population, ensure better life environment, and sustain the development in technology and economy (US EIA, 2017) (Sampaio \& Gonzalez, 2017). In meeting such energy demand, the annual total greenhouse gas (GHG) emissions from fossil fuels continue to increase as well (Sims, et al., 2007). In Asia alone, the reliance in fossil fuels is $86 \%$ in the energy mix which is 5\% higher than the global average (AIIB, 2017). There is therefore a need to extract energy from renewable sources as an alternative to fossil fuels. One option is solar which has become a popular choice for electricity generation owing to its being sustainable in terms of suitability, energy security and price becoming a dominant energy source among all other available sources of renewable energy (Wolfe, 2013).

Meteorological factors such as high temperature, dust and snow limit the maximum power potential from solar PV systems $\left(P_{P V}\right)$. High temperature, dust deposition and snow contribute to the decrease in $P_{P V}\left(\triangle P_{P V}\right)$ and their effects depends on season and location (Menes-Rodrìguez et al., 2005; Goossenset al, 1993; NAIT, 2016; Principe, Takeuchi, 2019). In our previous study to estimate the individual contributions to $\triangle P P V$ of the three meteorological parameters (Principe, Takeuchi, 2019), we used fixed values of temperature coefficient of efficiency $(d \eta / d T)$, solar cell efficiency, maximum nominal operating cell temperature $\left(\mathrm{NOTC}_{\max }\right)$ and snow coefficient of efficiency $(d \eta / d s)$, and a simple threshold value for aerosol optical depth (AOD) and observed its limitations on the modelled $P_{P V}$ output. This study presents an update to our model that estimates the effective $P_{P V}$ in the Asia Pacific region using remote sensing. With the updated model, the objective of this study is to assess the available solar PV power $(P P V)$ potential considering the effects of high temperature, dust and snow in the Asia Pacific region. Key cities in the region are also examined for a detailed analysis on the contribution of the said meteorological parameters to $\triangle P_{P V}$. Lastly, recommendations for solar PV installation in the region are presented to mitigate the effects of temperature, dust and snow in output power from solar.

\section{METHODOLOGY}

\subsection{Data}

Shortwave Radiation (SWR) and Cloud Property/Cloud Optical Thickness (CLOT) (both at $5 \mathrm{~km}$ and 10min) products are derived from the Advanced Himawari Imager 8 (AHI8) data and are downloaded via the Japan Aerospace Exploration Agency (JAXA) Himawari Monitor (eorc.jaxa.jp/ptree/index.ht$\mathrm{ml})$. To extract dust information, the daily Aerosol Optical Depth (AOD) from the MODIS aerosol product (MOD04 L2) at a resolution of $10 \mathrm{~km}$ was used (Levy et al., 2013). The mean monthly free-stream wind speed $\left(V_{f}\right)$ and air temperature $\left(T_{a}\right)$ from year 2001 to 2017 were downloaded and extracted from the National Centres for Environmental Prediction (NCEP) and 
National Center for Atmospheric Research (NCAR) Reanalysis (NCEP/DOE AMIP-II Reanalysis-2) data (https://www.esrl.noaa.gov/psd/). Meanwhile, precipitation rate data was extracted from the daily average rainfall estimates ( $0.1 \mathrm{deg}$ resolution) of the global satellite mapping of precipitation (GSMaP) (Okamoto et al., 2005). Lastly, the monthly Global 0.05deg CMG (version 6) MOD10 L3 dataset (Hall et al., 2001) is used to extract monthly snow cover. MOD10 product and snow water equivalent (SWE) product of AMSR-E were used to estimate snow depth. Due to the limitation of data availability, the period analysed for this is one complete year (March 2016 to February 2017) since the SWR data from AHI8 are only available from March 2016.

\subsection{Methods}

The general methodology for this study is shown in Fig.1. Various satellite data were processed to produce the theoretical and effective solar cell efficiency considering the effects of high temperature, dust and snow. Corresponding maps of solar PV potential over the Asia Pacific region were also produced.

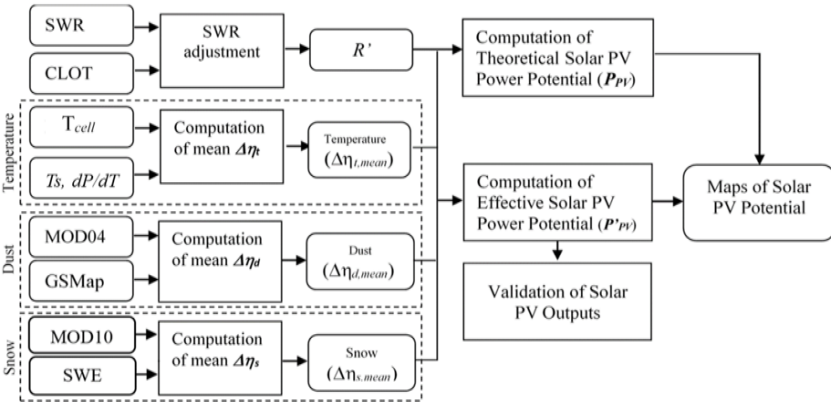

Figure 1. The flowchart of the methodology used in this study.

2.2.1 Adjustment of Shortwave Radiation from AHI8 This study utilized an approach of adjusting SR data from satellites based on the cloud optical thickness (CLOT) before evaluating the solar PV power potential. The idea lies on the fact that a change in CLOT also causes change in the amount of reflected radiation and alters the energy that can reach the atmosphere below the cloud layer and the earth's surface (Cotton et. al, 1992). The correction factor for solar radiation data was derived for each season. Seasons as defined in this study are: MAM (Mar to May), JJA (June-Aug), SON (SepNov) and DJF (Dec-Feb). A more detailed discussion of the technique is found in our previous publication (Principe, Takeuchi 2019).

2.2.2 Estimation of the Theoretical Solar PV Power Potential The theoretical solar PV power $\left(P_{P V}\right)$ output in megawatts (MW) is computed using Eq. (1):

$$
P_{P V}=A_{\text {cell }} \eta R^{\prime}
$$

where $A_{\text {cell }}$ is the total aggregated pixel area allocated for the installation of solar PV panels (effective pixel area, $E P A=17.5$ $\left.\mathrm{km}^{2}\right), \eta$ is the conversion efficiency of the solar cell, and $R^{\prime}$ is the adjusted solar radiation data from AHI8 (see Section 2.2.1). $E P A$ value was based on the final spatial resolution of the raster data used $(5 \mathrm{~km})$, and the assumption that only $70 \%$ of the pixel area will be utilized for PV solar installation.

\subsubsection{Estimation of Temperature Effects on $P_{P V}$}

The decrease in solar cell efficiency due to temperature $\left(\Delta \eta_{t}\right)$ was computed using Eq. (2). The over-bar in the equation indicates the computation of mean values over the evaluation period. $\Delta \eta_{t}$ is computed using the rated cell efficiency $(\eta)$, temperature coefficient of power $(d P / d T)$, cell operating temperature $\left(T_{c}\right)$, and temperature at standard test conditions (STC) $\left(T_{s}=25^{\circ} \mathrm{C}\right)$ at every $i^{\text {th }}$ day for each season with $n$ total number of days:

$$
\overline{\Delta \eta_{t}}=\eta \frac{d P}{d T} \frac{\sum_{i=1}^{n} T_{c}-T_{s}}{n}
$$

$d P / d T$ is usually provided in the manufacturer's technical manual. $T_{c}$ is estimated using a semi-empirical equation for PV module/array operating temperature (Skoplaki et al., 2008) with a mounting coefficient $\omega$ set to 1.8 for sloped roof PV array mounting type:

$$
T_{c}=T_{a}+\left(\frac{0.576}{8.91+2.0 V_{f}}\right) \times R_{\text {season }}^{\prime}
$$

\subsubsection{Estimation of Dust Effects on $P_{P V}$}

The decrease in solar cell efficiency due to dust $\left(\Delta \eta_{d}\right)$ is computed using a masking technique of Eq. (4):

$$
\begin{aligned}
\overline{\Delta \eta_{d}}=0.3 \frac{\sum_{i=1}^{n} x_{d_{i}} x_{r_{i}}}{n} \text { where } \quad x_{d i} & = \begin{cases}0, & \text { if } A O D \leq 0.2 \\
R_{R G B} & \text { otherwise. }\end{cases} \\
x_{r i} & = \begin{cases}0, & \text { if pcp_rate }>20 \mathrm{~mm} / \text { day } \\
1 & \text { otherwise. }\end{cases}
\end{aligned}
$$

where $n$ is the total number of days considered; the constant 0.3 is the reported decrease in solar cell efficiency due to dust by Sayigh (1978). The model considers only pixels with aerosol optical depth (AOD)>0.2 as a dust pixel and the value of $x_{d i}$ (mask for dust) is equal to the $\boldsymbol{R}_{\boldsymbol{r} g \boldsymbol{b}}$ component of AirRGB decomposition technique by Misra et al. (2017). Moreover, the ability of rain to clean the PV surface is considered only in pixels with precipitation rate (pcp_rate) greater than $20 \mathrm{~mm} /$ day (i.e., $x_{r i}=0$ ). The precipitation rate threshold is based on the suggestion of Kimber et al. (2006).

\subsubsection{Estimation of Snow Effects on $P_{P V}$}

Snow depth $(S N D)$ in $\mathrm{cm}$ is derived from the snow water equivalent $(S W E)$ product of AMSR-E and snow cover factor $(S C F)$ product of MODIS (MOD10) by assuming a fixed snow density of $0.3 \mathrm{~g} / \mathrm{cm}^{3}$ (Tedesco, 2012). The decrease in solar cell efficiency due to snow $\left(\Delta \eta_{s}\right)$ at every $i^{\text {th }}$ month for each season with $n$ total number of months is estimated using $S N D$ as given in Eq. (5):

$$
\overline{\Delta \eta_{s}}=\frac{\sum_{i=1}^{n} \Delta \eta_{s, i}}{n} \text { where } \Delta \eta_{s, i}=\left\{\begin{array}{cl}
0 & \text { if } S N D_{i}=0 \\
1-0.542 e^{-0.221 \times S N D_{i}} & \text { elif } 0<S N D_{i}<12 \\
1 & \text { elif } S N D_{i} \geq 12
\end{array}\right.
$$

The equation to compute $\Delta \eta_{s}$ for $0<\mathrm{SND}<12$ was derived via a curve-fitting technique based on the observations of light transmission by snow made in a quasi-laboratory setting (Perovich, 2007) for wavelength of $550 \mathrm{~nm}$ which represents the bands of AHI-8 used in the derivation of SWR product (Frouin, Murakami, 2007; Lee et al., 2018). 


\subsubsection{Effective PV Power $\left(P^{\prime}{ }_{P V}\right)$}

The effective PV power $\left(P^{\prime} P V\right)$ is defined as the theoretical PV power minus the power output lost due to the combined effects of high temperature, dust and snow. Eq. (6) gives the total decrease in efficiency and effective PV power $\left(P^{\prime} P V\right)$ :

$$
P_{P V}^{\prime}=A_{\text {cell }} \eta R^{\prime}\left(1-\overline{\Delta \eta_{t}}-\overline{\Delta \eta_{d}}-\overline{\Delta \eta_{s}}\right)
$$

Variables in Eq. (6) are defined in the previous sections of this paper (Sections 2.2.2 to 2.2.5).

\subsubsection{Validation of Solar PV Outputs}

The estimated effective PV power $\left(P^{\prime} P V\right)$ using the model was compared with the measured power outputs from actual solar PV installations in Perth, Australia ( $\mathrm{SH}$ : Signal Hill) and Bangkok, Thailand (BF: Bangkok Frecon). The measured PV power outputs from the said installations were extracted from PVOutput.org (https://pvoutput.org). The website offers a free service platform to share, compare and monitor live solar photovoltaic (PV) and energy consumption data (PVOutput.org, 2018). Since the reported actual outputs were in energy units (kWh), the computed $P^{\prime}{ }_{P V}$ in MW must be converted to kWh using the method we presented in our previous paper (Principe, Takeuchi, 2019).

The description of the two solar PV installations used in this study for validation purposes is shown in Table 1 . Only this limited number of actual solar PV systems were used because there were only a few installations in Asia Pacific region with data in PVOutput.org and most of them did not have data for periods covered in this study.

Table 1. Actual solar PV installations in PVOutput.org used for validation of monthly and seasonal model outputs.

\begin{tabular}{ccccccc}
\hline \hline Sta. & Location & $\begin{array}{c}\text { Size } \\
(\mathrm{kW})\end{array}$ & Orientation & $\begin{array}{c}\text { Tilt } \\
(0)\end{array}$ & $\begin{array}{c}\mathrm{dP} / \mathrm{dT} \\
(\% / K)\end{array}$ & $\begin{array}{c}\eta \\
(\%)\end{array}$ \\
\hline SH & $\begin{array}{c}\text { Perth, } \\
\text { Australia }\end{array}$ & 3.36 & $\mathrm{NE}$ & 18 & -0.38 & 16.90 \\
$\mathrm{BF}$ & $\begin{array}{c}\text { Bangkok, } \\
\text { Thailand }\end{array}$ & 45.6 & $\mathrm{~S}$ & 13 & -0.47 & 17.47 \\
\hline \hline
\end{tabular}

The model's performance was evaluated using the percentage prediction error (PPE) as given by Kim et al. (2017) in Eq. (7):

$$
P P E=\frac{\left|V_{P}-V_{M}\right| \times 100}{V_{M}}
$$

where $V_{P}$ and $V_{M}$ are the predicted $\left(P^{\prime}{ }_{P V}\right)$ and measured (actual) values, respectively. Eq. (7) implies a better $P^{{ }^{\prime}}{ }_{P V}$ estimation for lower $P P E$ values.

\section{RESULTS AND DISCUSSIONS}

\subsection{Theoretical Solar PV Power Potential $\left(P_{P V}\right)$ in the Asia Pacific Region}

The spatial distribution of $P_{P V}$ is shown in Fig. 2. The maximum value of $P_{P V}$ in the region was estimated at $\sim 2.5 \mathrm{GW}$ per $A_{\text {cell }}$ of $17.5 \mathrm{~km}^{2}$ for a solar cell efficiency of $17.47 \%$ (the case of solar PV installation in Bangkok). Solar PV installations in many parts of the Asia Pacific region is estimated to produce high output power during the JJA season except in Southern Australia and mountainous areas in India, Nepal, Myanmar and Bhutan. Topographic shading and short sunshine hours (in case of Australia) are possible reasons for the low $P_{P V}$ potential during the said season. Moreover, the seasonal variation of the estimated $P_{P V}$ for selected cities in the region is shown in Fig. 3. $P_{P V}$ varies depending on the location and season of the year, with maximum values estimated in Brunei and Muara (1664.14 MW and 1716.74 MW in SON and JJA, respectively), Sydney (1837.56 MW in DJF), and Manila (1996.10 MW in MAM).

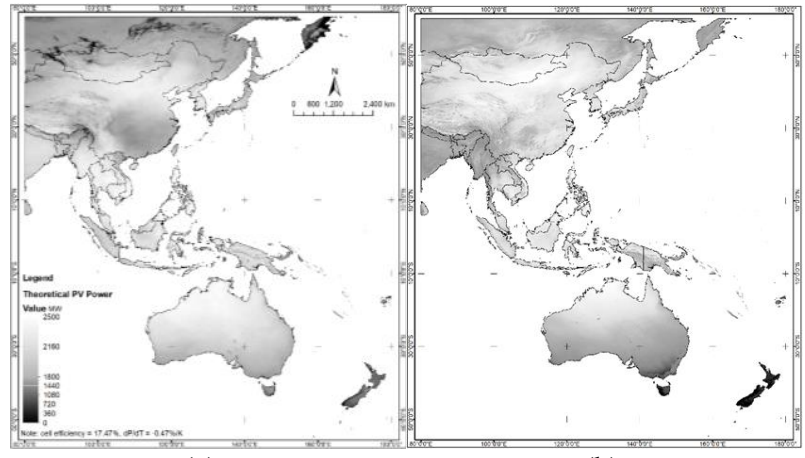

(a)

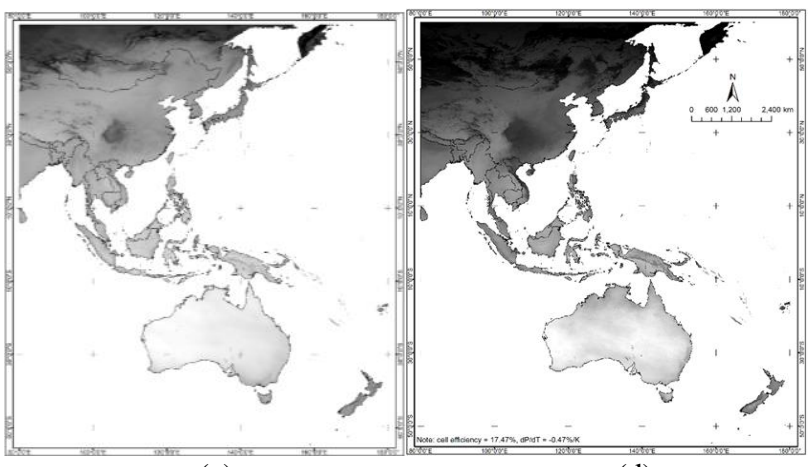

(c) (b)

(d)
Figure 2. Theoretical mean seasonal solar PV power (in megawatts) in the Asia Pacific region: (a) MAM; (b) JJA; (c) SON; (d) DJF.

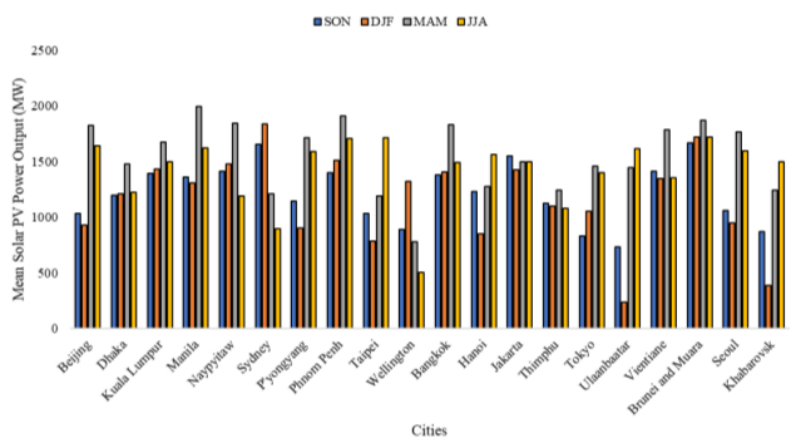

Figure 3. Theoretical mean seasonal solar PV power $\left(P_{P V}\right)$ output for selected cities in the Asia Pacific region.

\subsection{Effects of High Temperature, Dust and Snow to $P_{P V}$}

Maps showing the combined effects of the three meteorological factors to solar cell efficiency are displayed in Fig. 4. Moreover, Fig. 5 shows the percentage decrease in $P_{P V}\left(\Delta P_{P V}\right)$ during different seasons at selected cities in the region. The maximum $\triangle P_{P V}$ due to high temperature, dust and snow were estimated at $2 \%, 22 \%$ and $100 \%$, respectively. Maximum values are observed for Khabarovsk in all seasons $(-30 \%,-83 \%,-41 \%$, $12 \%)$ while second were Ulaanbaatar $(-24 \%,-61 \%,-28 \%)$ and Beijing (-7.34\%) during SON, DJF, MAM and JJA seasons, respectively (Fig. 5). 
The cities of Beijing (China), Khabarovsk (Russia) and Jakarta (Indonesia) were selected to see the percent contribution of the three meteorological factors considered in this study to the overall decrease in solar PV potential with respect to the theoretical values. Fig. 6a shows that in Beijing's case, dust and snow are the major factors which contributed to the decrease in $P_{P V}$ for MAM season. Moreover, the major contributors affecting the said decrease during DJF and JJA seasons are snow and dust, respectively. Almost half of theoretical $P_{P V}(49.57 \%)$ was estimated to be lost due to snow during DJF season. Lastly, temperature has very negligible effects on PPV with a constant percentage value of only $0.52 \%$ in all seasons.

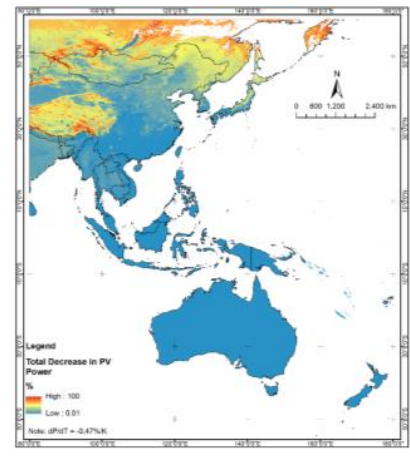

(a)

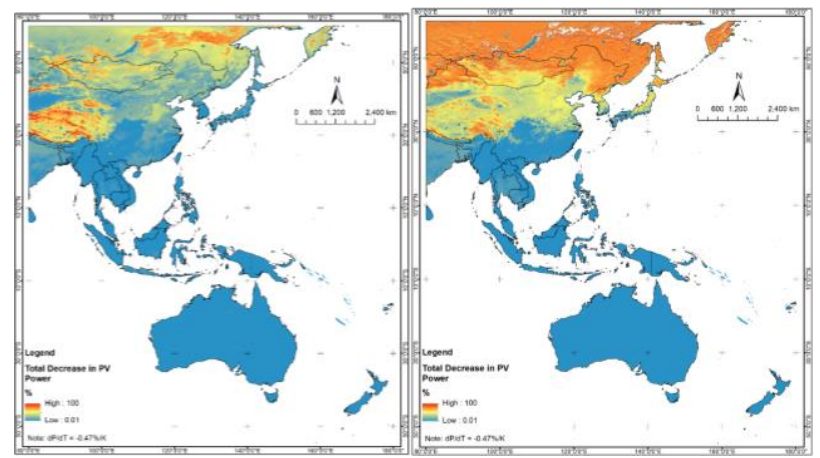

(c)

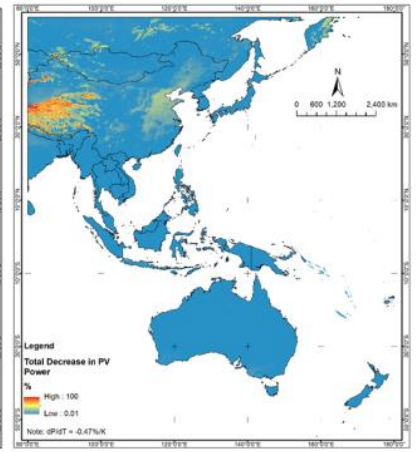

(b)
Figure 4. Total effect of temperature, dust and snow to seasonal PPV: (a) MAM, (b) JJA, (c) SON, (d) DJF.

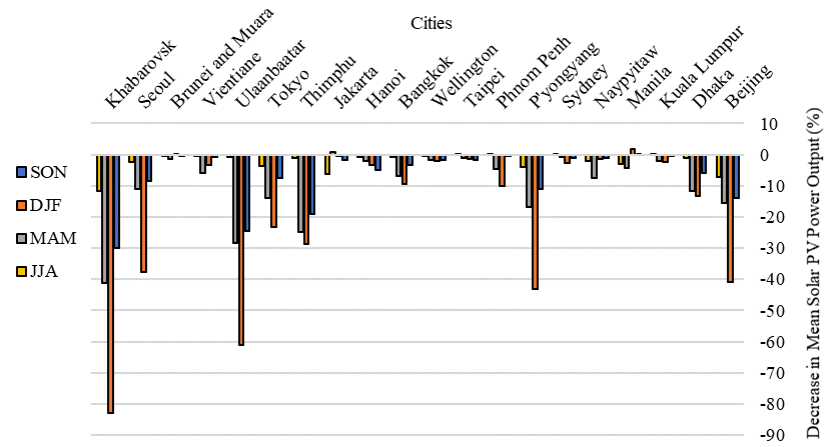

Figure 5. Decrease in mean seasonal solar PV power potential for selected cities in the Asia Pacific region.

Khabarovsk is severely affected by snow all throughout the year and exceptionally during DJF and SON seasons, especially during DJF when about $98 \%$ of the theoretical PV output was lost due to snow (Fig. 6b). Temperature has very negligible effects $(0.52 \%$ in all seasons) while $6 \%$ of the lost power was due to dust has the highest effect during JJA.

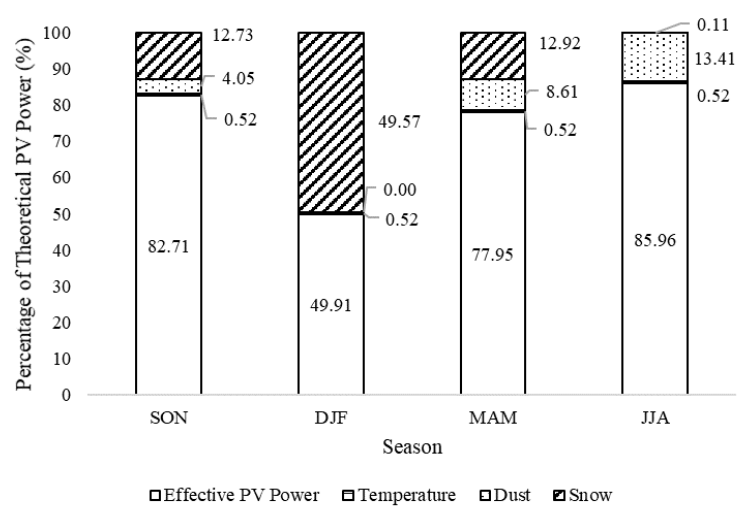

(a)

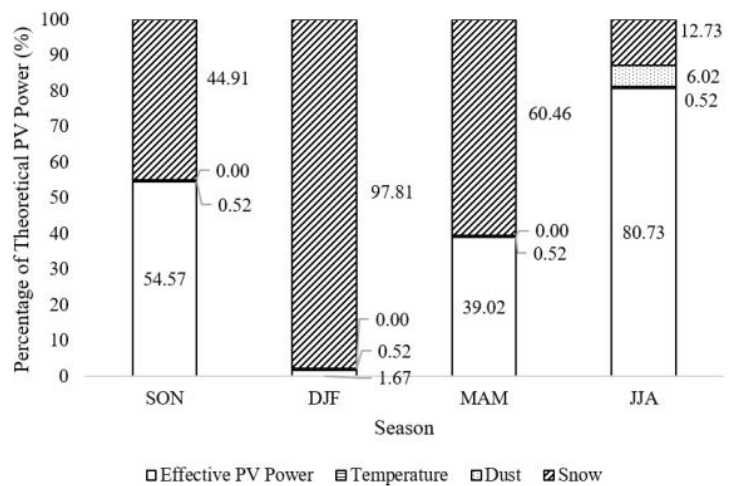

(b)

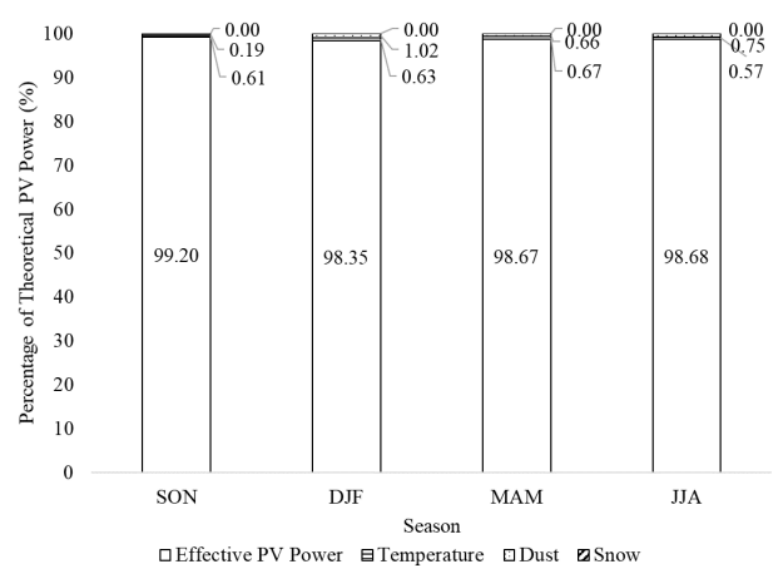

c)

Figure 6. Decrease in PV power due to snow, dust and temperature, and the resulting effective PV power (labels from top to bottom, respectively, for each season) as percentages of the theoretical solar PV power $\left(P_{P V}\right)$ in (a) Beijing, China; (b)

Khabarovsk, Russia; and (c) Jakarta, Indonesia.

In the case of Jakarta, the three meteorological parameters did not have significant effect to $\boldsymbol{P}_{\boldsymbol{P V}}$ considering their percentage of contribution to the decrease in $\boldsymbol{P}_{\boldsymbol{P V}}$ was less than $1 \%$ for all seasons, except during DJF where dust effect was estimated at $1.02 \%$ of $\boldsymbol{P}_{\boldsymbol{P V}}$ (Fig. 6c). Finally, since Jakarta is in the tropics, it is obvious that snow has no effect to this part of the region.

Figure 7 shows in RGB display the spatial distribution of the mean monthly effects of the three meteorological factors to the percent decrease in PV power $(D P P V)$ for the Asia Pacific region. The red, green and blue bands correspond to the effects of temperature, dust and snow, respectively. As such, for pixels 

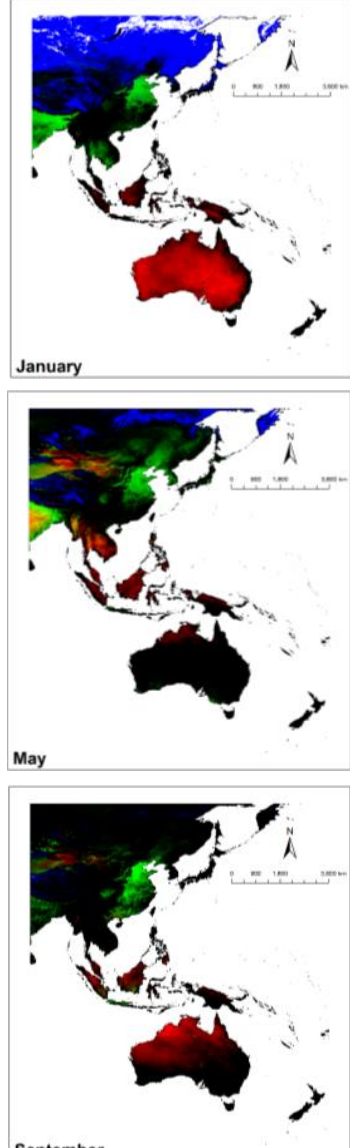

September
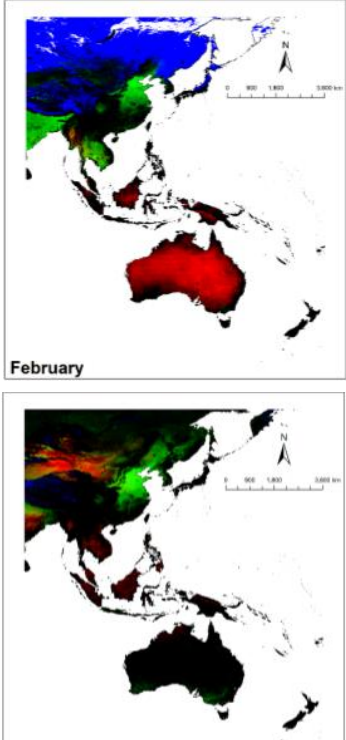

June

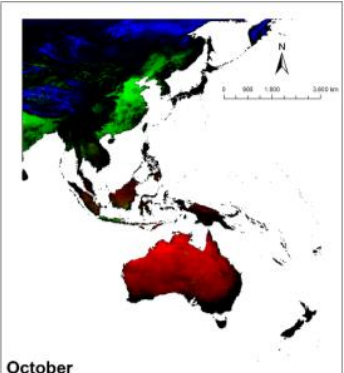

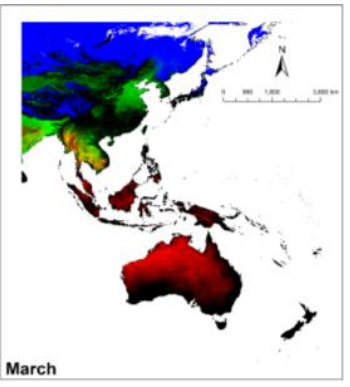
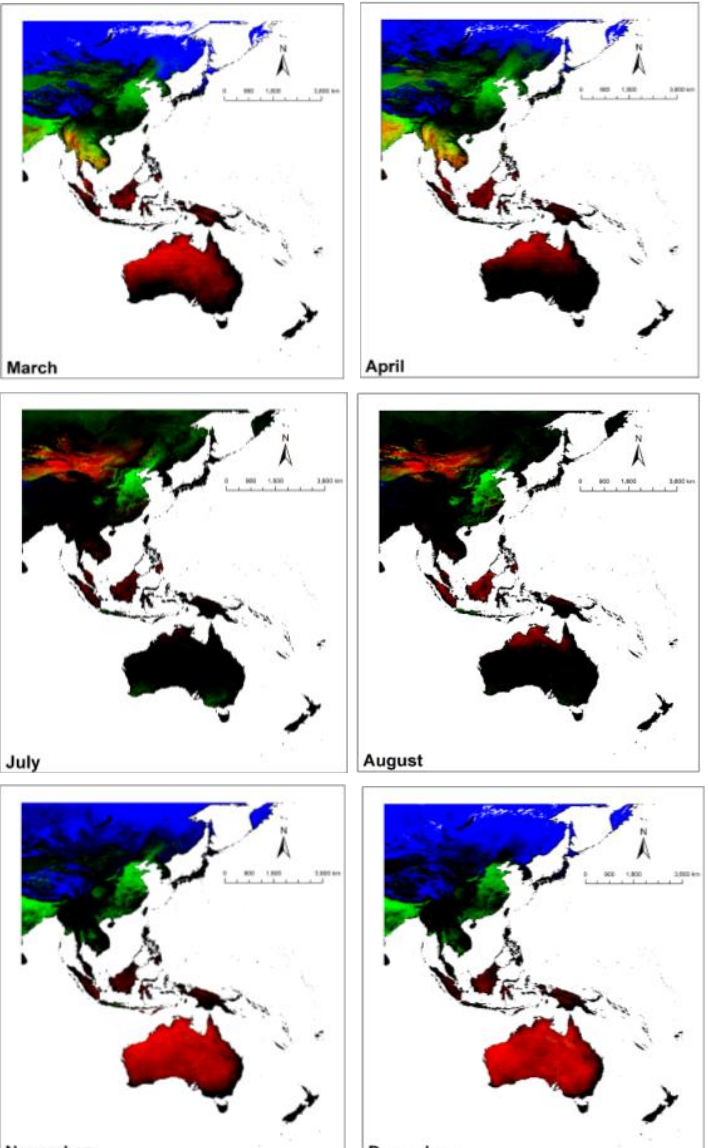

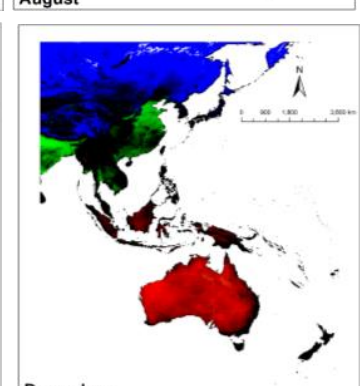

Figure 7. Mean monthly effects of temperature (Red), dust (Green) and snow (Blue) in RGB display (color wheel is shown in Fig. 8).

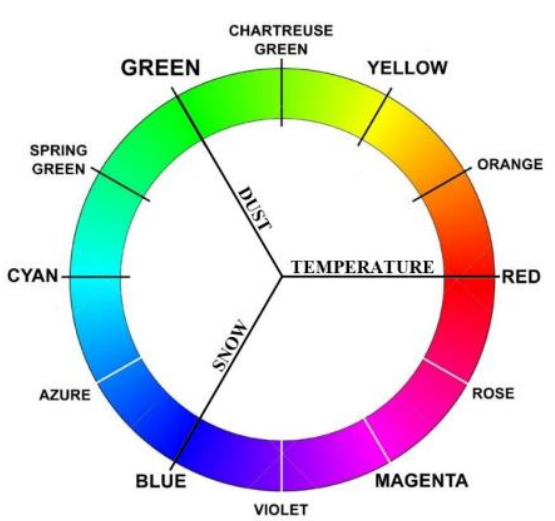

Figure 8. Color wheel of RGB display of Fig. 7. Pixels significantly affected by temperature, dust and snow will be displayed in red, green and blue, respectively. Meanwhile, pixels with same values for the effects of dust and temperature, temperature and snow, and snow and green, will be displayed in yellow, magenta and cyan, respectively. (Original image taken from https://www.123rf.com)

which are pure red, the effect of temperature is the most significant compared to dust and snow. Conversely, for pixels displayed in pure green and pure blue, the most significant meteorological factor affecting the decrease in PV power is dust and snow, respectively. A color wheel shown in Fig. 8 is created to assist in visual interpretation. For pixels with same $D P_{P V}$ value for dust and temperature, temperature and snow, and snow and dust will be displayed in yellow, magenta, and cyan colors, respectively. Meanwhile, if all three bands have 0- or 100-pixel values, the corresponding pixel will be displayed in black or white, respectively.

Australia was only affected mostly by temperature all throughout the year as signified by red pixels within its territories. Bangladesh was mostly covered with green pixels in January since the country was only affected by dust (mean $\Delta P_{P V}$ $=19 \%$ ) during this month. Lastly, most of the northernmost areas in the region are consistently affected by snow during winter season as evidenced by the bluish pixels in December, January and February. Temperature and dust were both affecting central Myanmar (e.g., Magway Region) in April as seen by yellow pixels surrounding the area. The effects of snow and dust were observed in the eastern provinces of China during the month of December as depicted by the spring green to cyancolored pixels. Meanwhile, there were no magenta-colored pixels observed since snow and high temperature cannot occur simultaneously.

Results of model estimation on $\Delta P_{P V}$ showed negligible effects of high temperature on $P P V$ and therefore much of the efforts must be put on mitigating the negative impacts of dust and snow on solar PV power generation. Analyzing the frequency and intensity of rain in the region, we found out that manual cleaning of solar panels is still recommended as rainfall alone cannot serve as an effective natural cleaning agent (Principe, Takeuchi, 2018). Moreover, consistent but careful wiping off snow is recommended for installation in snow-affected regions. 


\subsection{Estimated effective solar PV power $\left(P^{\prime}{ }_{P V}\right)$ potential}

During MAM, areas in Russia and the Himalayan regions of Nepal, Bhutan and Tibet were estimated to experience zero power output due snow (Fig. 7). Moreover, some parts of India, Myanmar, Thailand and Cambodia experience low $P^{\prime}{ }_{P V}$ due to the combined effects of temperature and dust. During JJA season, areas in India, North East China and Western Mongolia have lower $P^{\prime}{ }_{P V}$ due to dust and very high temperatures. Meanwhile, high temperature, dust, and snow affect only some parts of northeast Australia, China, and Russia, respectively, during SON season. Lastly, high temperatures in Australia and snow in Russia and northern Japan limit the PV power outputs in these areas during DJF season. Cities with the highest estimated mean seasonal effective PV power $\left(P^{\prime} P V\right)$ are Brune \& Muara (1662 MW), Sydney (1791 MW), Manila (1912 MW), and Taipei (1717 MW) during the SON, DJF, MAM, and JJA seasons, respectively (Fig. 8).

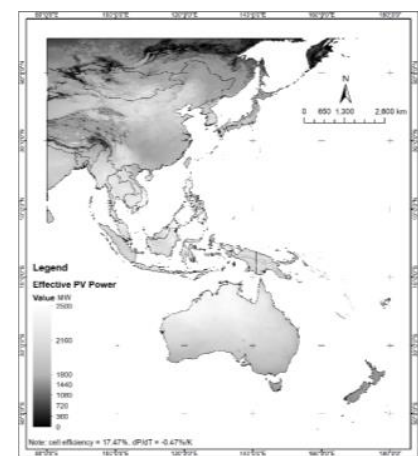

(a)

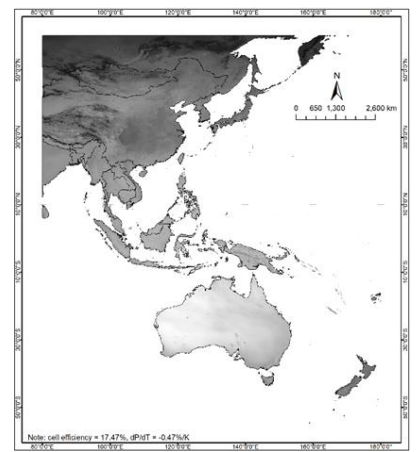

(c)

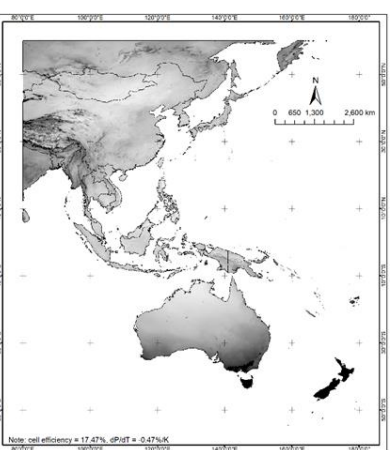

(b)

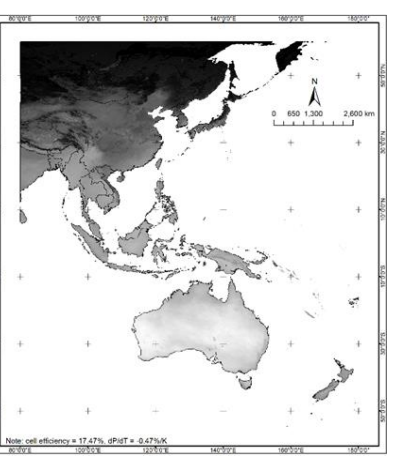

(d)
Figure 7. Effective mean seasonal PV power $\left(P^{\prime}{ }_{P V}\right)$ (in megawatts) considering the effects of temperature, dust and snow in the Asia Pacific region: (a) MAM; (b) JJA; (c) SON; (d) DJF.

\subsection{Validation of Model Outputs}

Table 2 provides a summary of $P P E$ values from the estimated (effective) and measured mean monthly solar PV outputs for the two installations in Australia and Thailand. For monthly estimations in SH station, the model underestimated the PPE from April to October, the period when the average daily solar exposure is relatively less intense than the rest of the year in Perth, Australia (Australian Bureau of Meteorology, 2016). There is also an underestimation of $P P E$ in $\mathrm{BF}$ station for most part of the year except during Dec to Feb and Apr when the average monthly sunshine hours are longer than other months of the year (Thai Meteorological Department, 2014). For seasonal estimations, the model underestimated the generated seasonal energy throughout the year for both $\mathrm{SH}$ and $\mathrm{BF}$ installations except during DJF for SH station when the PV output is overestimated by $26 \%$ compared to the measured value (Table 3). Additionally, Fig. 9 shows the bar charts of the mean monthly estimated and measured PV outputs for the two installations. The mean monthly PPE values of $5 \%$ and $7 \%$ for $\mathrm{SH}$ and BF, respectively, implying good agreement between model estimations and measured values. Fig. 9 also shows the seasonality of PV outputs which has different trend for the two stations. In SH station, the peak of $P_{P V}$ occurs in December and decreases thereafter until June. $P_{P V}$ will then increase starting July until it reaches the peak in December. A different trend can be observed for $\mathrm{BH}$ station where maximum $P_{P V}$ is observed during MAM months and decreases thereafter. Such information on solar PV output seasonality is crucial in planning for any future installations to estimate the maximum and minimum power that can be produced by the said renewable energy system.

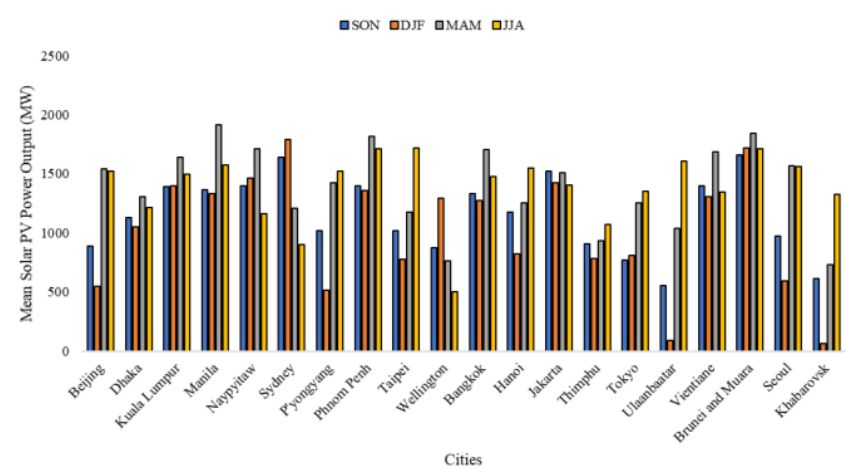

Figure 8. Effective mean seasonal solar PV power $\left(P^{\prime}{ }_{P V}\right)$ output for selected cities in the Asia Pacific region.

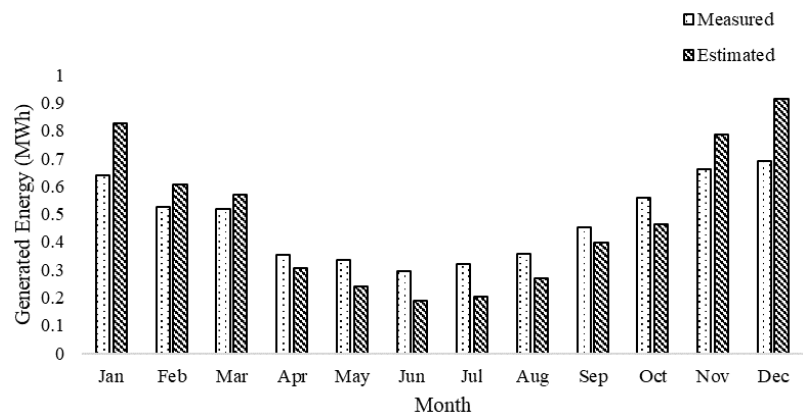

(a)

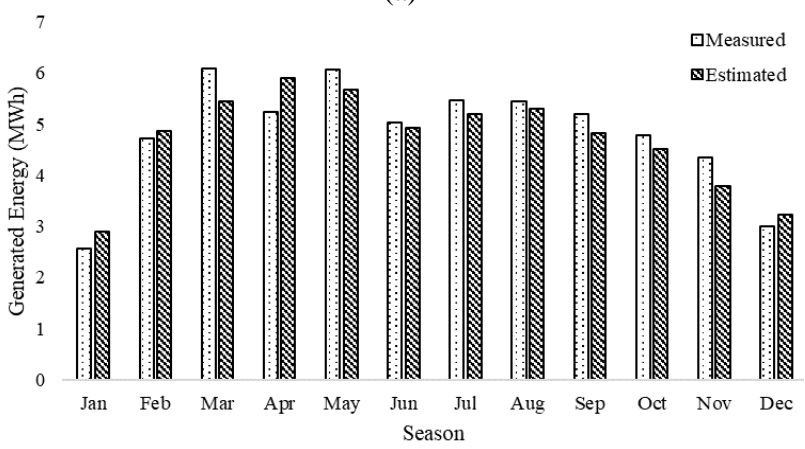

(b)

Figure 9. Comparison of estimated (effective) and measured energy in: (a) Signal Hill (SH) and (b) Bangkok Frecon (BF) solar PV installations. There is model underestimation during Apr to Oct while overestimation in Jan to Mar and Nov to Dec in SH. Meanwhile the model underestimates generated energy in BF throughout the year except in Jan, Feb and Apr. 
Table 2. Validation results for mean monthly solar PV outputs.

\begin{tabular}{|c|c|c|c|c|c|c|}
\hline \multirow{2}{*}{$\begin{array}{l}\text { PV } \\
\text { Sta. }^{+}\end{array}$} & \multicolumn{6}{|c|}{ Mean Monthly PPE (\%)* } \\
\hline & Jan & Feb & Mar & Apr & May & Jun \\
\hline $\mathrm{SH}$ & $(+) 30$ & $(+) 16$ & $(+) 10$ & $(-) 12$ & (-) 28 & $(-) 35$ \\
\hline $\mathrm{BF}$ & (+) 13 & $(+) 3$ & $(-) 10$ & (+) 12 & $(-) 6$ & $(-) 2$ \\
\hline PV & \multicolumn{6}{|c|}{ Mean Monthly $P P E(\%)^{*}$} \\
\hline Sta. $^{+}$ & Jul & Aug & Sep & Oct & Nov & Dec \\
\hline $\mathrm{SH}$ & $(-) 36$ & (-) 24 & $(-) 11$ & $(-) 16$ & $(+) 19$ & $(+) 33$ \\
\hline BF & (-) 4 & $(-) 2$ & $(-) 7$ & (-) 5 & $(-) 13$ & $(+) 7$ \\
\hline
\end{tabular}

${ }^{+}$SH: Signal Hill, BF: Bangkok Frecon

$*(-)$ and $(+)$ denote model under- and overestimation, respectively

Table 3. Validation results for mean seasonal solar PV outputs.

\begin{tabular}{lcccc}
\hline \hline PV & \multicolumn{4}{c}{$P P E(\%) *$} \\
Station $^{+}$ & MAM & JJA & SON & DJF \\
\hline SH & $(-) 10$ & $(-) 32$ & $(-) 2$ & $(+) 26$ \\
BF & $(-) 2$ & $(-) 3$ & $(-) 9$ & $(-) 7$ \\
\hline \hline
\end{tabular}

${ }^{+} \mathrm{SH}$ : Signal Hill, BF: Bangkok Frecon

$*(-)$ and $(+)$ denote model under- and overestimation, respectively

Validation results showed that the model has mean PPE ranges of $5 \%$ to $18 \%$ and $7 \%$ to $23 \%$ in seasonal and monthly estimations, respectively. This result was close to but better than the reported mean monthly PPE value $(23.6 \%)$ by Kim et al. (2017) who employed a "practical model" (similar in some respect to our model, except that they did not consider the effects of high temperature, dust and snow) for daily prediction of solar PV power generation in South Korea. The model used in this study still needs further refinement since some months can have $P P E$ values reaching up to $>30 \%$ with under- and over-estimations of $P_{P V}$ values compared to the measured solar PV outputs. The semi-empirical equation for PV module/array operating temperature was not validated with measured cell temperature $\left(T_{c}\right)$ values due to limitations on data availability. As such, the model can further be improved by ensuring that the estimated $T_{c}$ were accurate and realistic compared to measured values from different solar PV installations or actual $T_{c}$ from a time series of measured values. The maximum decrease in solar cell efficiency due to dust was set at a maximum fixed value (30\%) based on previous research findings which may not be true for some areas in the region. As such, a more flexible value for the said parameter which varies per location and season may be more appropriate. Moreover, the snow depth estimation must also be improved to reflect the actual values on the ground as this can dictate whether the PV system can produce power. These concerns must be dealt with in further updates of the model.

For future study, we plan to use high resolution digital surface models (DSM) to extract rooftops and estimate $P_{P V}$ based on the roof's tilt, orientation and available installation area per house, as well as to estimate shadow effects. This study will also be extended to consider the socioeconomic aspect of solar PV installation in the Asia Pacific region. We will be considering the levelized cost of electricity (LCOE) for solar PV and assess the affordability of solar home systems (SHS) to support the national electrification efforts for each country in the region with special attention to providing electricity to off-grid areas.

\section{CONCLUSIONS}

Asia Pacific is a solar-rich region. Notwithstanding the effects of high temperature, dust, and snow, the region was estimated to yield a high solar PV power $\left(P_{P V}\right)$ potential at $2.5 \mathrm{GW}$ per effective pixel area of $17.5 \mathrm{~km}^{2}$. Such high potential was due to the estimated negligible effects of high temperature, only up to $22 \%$ reduction of $P_{P V}\left(\triangle P_{P V}\right)$ due to dust in some parts of the region and snow affecting only countries in the northernmost region during December-January-February (DJF) season. Such information is necessary in planning for any solar PV project since the effects of high temperature, dust and snow to $P_{P V}$ vary with location and season. Manual cleaning from dust and wiping off snow on solar panels are recommended to mitigate the negative effects of the said meteorological factors contributing to $\triangle P P V$. Further updates to the model can be done by using a more realistic $T_{c}$, making the decrease in solar cell efficiency due to dust to vary, and updating snow depth estimation to make it more accurate at finer time resolution.

With the increasing global demand for energy, the option to tap power from renewable energy sources such as solar has becoming a more popular choice due to its being sustainable in many aspects. A holistic approach of assessing the potential of solar PV power in the Asia Pacific region is therefore necessary to meet this demand for energy, and utilization of remote sensing and GIS technologies can become powerful tools in doing such assessment.

\section{ACKNOWLEDGEMENTS}

The authors would wish to thank the Japan Aerospace Exploration Agency (JAXA) for the SWR, CLOT and GSMaP products supplied by the P-tree System; and the Hitachi Global Foundation for their support in this research endeavor.

\section{REFERENCES}

AIIB, 2017. Energy Sector Strategy: Sustainable Energy for Asia. Asian Infrastructure Investment Bank. https://www.aiib.org/en/policies-strategies/strategies/sustainable -energyasia/.content/index/_download/energy-sector-strategy. pdf (9April2018).

Australian Bureau of Meteorology, 2016. Average annual \& monthly sunshine duration. http://www.bom.gov.au/jsp/ncc/climate_averages/sunshine-hours/ (May 17, 2019).

Cotton, W. R., Bryan, G., van den, S. C., 1992: Radiative Transfer in a Cloudy Atmosphere and Its Parameterization. International Geophysics, 44, 148-189.

Frouin, R., Murakami, H., 2007: Estimating Photosynthetically Available Radiation at the Ocean Surface from ADEOS-II Global Imager Data. Journal of Oceanography, 63, 493-503.

Goossens, D., Offer, Z., A., Z., 1993: Wind tunnel experiments and field investigations of eolian dust deposition on photovoltaic solar collectors. Solar Energy 50, 75-84.

Hall, D. K., Riggs, G. A., \& Salomonson, V. V. (2001). Algorithm Theoretical Basis Document (ATBD) for the MODIS Snow and Sea Ice-Mapping Algorithms. NASA. https://modissnow-ice.gsfc.nasa.gov/?c=atbd\&t=atbd (5April2018). 
Kim, J., Kim, D., Yoo, W., Lee, J., Kim, Y. B., 2017: Daily prediction of solar power generation based on weather forecast information in Korea. IET Renew. Power Gener., XI (10), 12681273.

Kimber, A., Mitchell, L., Nogradi, S., Wenger, H., 2006: The Effect of Soiling on Large Grid-Connected Photovoltaic Systems in California and the Southwest Region of the United States. 2006 IEEE 4th World Conference on Photovoltaic Energy Conference, 2391-2395. doi.org/10.1109/WCPEC.2006 .279690 .

Lee, S.-H., Kim, B.-Y., Lee, K.-T., Zo, I.-S., Jung, H.-S., Rim, S.H., 2018: Retrieval of Reflected Shortwave Radiation at the Top of the Atmosphere Using Himawari-8/AHI Data. Remote Sensing, 10(2), 1-25.

Levy, R. C., Mattoo, S., Munchak, L. A., Remer, L. A., Sayer, A. M., Patadia, F., Hsu, N. C., 2013: The Collection 6 MODIS aerosol products over land and ocean. Atmospheric Measurement Techniques, 6, 2989-3034.

Menes-Rodrìguez, D., Horley, P., Gonzàlez-Hernàndez, J., Vorobiev, Y., Gorley, P., 2005: Photovoltaic solar cell performance at elevated temperatures. Sol. Energy (78), 243250 .

Misra, P., Fujikawa, A., Takeuchi, W., 2017: Novel Decomposition Scheme for Characterizing Urban Air Quality with MODIS. Remote Sensing 9(8), 1-19.

NAIT, 2016. Alternative Energy Program: Solar Photovoltaic Reference Array Report. Northern Alberta Institute of Technology. https://solaralberta.ca/sites/default/files/ NAIT\%20 Reference\%20Array\%20Report.pdf (05April2018).

Okamoto, K., Iguchi, T., Takahashi, N., Iwanami, K., Ushio, T., 2005. The Global Satellite Mapping of Precipitation (GSMaP) project. 25th IGARSS, 3414-3416. doi.org/ 10.1109/IGARSS.20 05.1526575 .

Perovich, D. K., 2007: Light reflection and transmission by a temperate snow cover. Journal of Glaciology, 53(181), 201210.

Principe, J., \& Takeuchi, W, 2018. Dust Analysis and its Effects on Solar PV Power Potential in the Asia Pacific Region Using MODIS Time-Series from 2001-2017. Proceedings Asian Conference on Remote Sensing 2018, 2509-2518.

Principe, J., Takeuchi, W., 2019: Assessment of solar PV power potential over Asia Pacific region with remote sensing considering meteorological factors. Journal of Renewable and Sustainable Energy, 11(1), 0135021-16. doi.org/10.1063/1.505 9335.

Sampaio, P., Gonzalez, M., 2017: Photovoltaic solar energy: Conceptual framework. Renewable and Sustainable Energy Reviews 74, 590-601. doi.org/10.1016/j.rser.2017.02.081.

Sayigh, A., 1978. Effect of dust on flat plate collectors. Sun, mankind's future source of energy. Proceedings of the international solar energy society congress, 960-964.

Sims, R.E.H., R.N. Schock, A. Adegbululgbe, J. Fenhann, I. Konstantinaviciute, W. Moomaw, H.B. Nimir, B. Schlamadinger, J. Torres-Martínez, C. Turner, Y. Uchiyama,
S.J.V. Vuori, N. Wamukonya, X. Zhang, 2007: Energy supply. In Climate Change 2007: Mitigation. Contribution of Working Group III to the Fourth Assessment Report of the Intergovernmental Panel on Climate Change [B. Metz, O.R. Davidson, P.R. Bosch, R. Dave, L.A. Meyer (eds)], Cambridge University Press, Cambridge, United Kingdom and New York, NY, USA.

Skoplaki, E., Boudouvis, A., Palyvos, J., 2008: A simple correlation for the operating temperature of photovoltaic modules of arbitrary mounting. Solar Energy Materials \& Solar Cells (92), 1393-1402. doi.org/10.1016/j.solmat.2008.05.016.

Tedesco, M., 2012. Algorithm Theoretical Basis Document Snow Algorithm. City University of New York. https://nsidc.org/sites/nsidc.org/files/technical-references/amsratbd-supp12-snow.pdf (13September2018).

Thai Meteorological Department, 2014. Agrometeorology. https://www.tmd.go.th/agromet.php (05April2018).

US EIA, 2017. International Energy Outlook 2017. Independent Statistics and Analysis: US Energy Information Administration. https://www.eia.gov/outlooks/ieo/ (9April2018).

Wolfe, P., 2013: Solar Photovoltaic Projects in the Mainstream Power Market. Routledge, New York. 